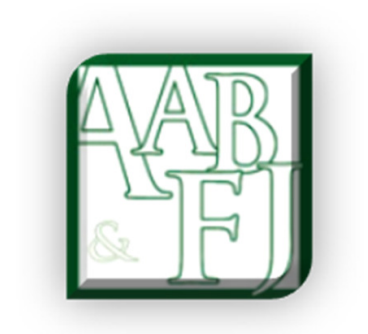

\title{
Corporate Governance Effects on Social Responsibility Disclosures
}

\author{
António Dias ${ }^{1}$, Lúcia Lima Rodrigues ${ }^{2}$ and Russell Craig ${ }^{3}$
}

\begin{abstract}
This study uses stakeholder theory to explore how corporate governance [CG] characteristics influence corporate social responsibility disclosure [CSRD] in the context of a global financial crisis [GFC]. Empirical data are drawn from Portugal, a country strongly affected by the GFC. Portuguese companies are characterized by high ownership concentration. The largest shareholder is often the CEO and Board Chair (a phenomenon known as CEO duality). We analyse the association between CSRD (measured by a 40-item disclosure index) and CG variables (board size, CEO duality, board independence, ownership concentration and presence of an audit committee or CSR committee) for 48 of the 51 listed companies in Portugal. The control variables are company size and industry type.

We find that CSRD is affected positively by board size, CEO duality, company size and industry type. This accords with suggestions implicit in stakeholder theory that a larger board will represent a broader diversity of stakeholders and will promote better monitoring, more assertive stakeholder management, greater transparency, and increased levels of CSRD. Larger companies and companies close-to-consumers are associated with high levels of CSRD, ostensibly because they are more visible and subject to greater societal monitoring during a period of financial crisis. We reveal that in a country characterized by high ownership concentration, CEO duality has a positive effect on CSRD.
\end{abstract}

JEL Classification: M14

Keywords: Corporate social responsibility disclosure, corporate governance, ownership concentration, stakeholder theory, Portugal.

\footnotetext{
${ }^{1}$ CETRAD, and University of Trás-os-Montes, Vila Real, Portugal. Email: acgdias@ gmail.com

${ }^{2}$ GOVCOPP, University of Aveiro, and School of Economics and Management, University of Minho, Gualtar Campus, Braga 4709, Portugal. Email: 1rodrigues@eeg.uminho.pt

${ }^{3}$ Portsmouth Business School, University of Portsmouth, Portland Street, Portsmouth, Hampshire PO1 3DE

United Kingdom. Email: Russell.Craig@port.ac.uk
} 


\section{Introduction}

The overriding objective of business activity has evolved from a classical, largely unfettered quest for profit maximizing, to one of seeking profit in a socially responsible way. In a period of ongoing global financial crisis (GFC) in some European countries (such as Portugal, Greece and Spain, where the effects were pronounced and are on-going), this evolution has directed keen attention to the efficacy of Corporate Governance (CG) mechanisms and the extent and quality of Corporate Social Responsibility Disclosure (CSRD) practices.

A company board of directors is responsible for instituting appropriate mechanisms to monitor and control company activity. The board is responsible also for a company's accountability and transparency through information disclosure. Boards have collective obligations to a wide range of stakeholders. However, there has "been little research linking corporate disclosure to governance structures" (Akhtaruddin et al., 2009, p.1). As a consequence, there is a strong need to examine the influence of board composition on CSR activity and CSRD (Rao \& Tilt, 2015). Involvement in CSR, and associated disclosures, stems from board decisions (Ho \& Wong, 2001; Gul \& Leung, 2004; Haniffa \& Cooke, 2005; Cheng \& Courtenay, 2006). Nonetheless, knowledge of how the CG characteristics of boards influence CSRD is under-developed (Khan et al., 2013).

One shortcoming in the CG and CSRD literature is the low-level of research in the context of economic and financial crises. This is something the present study addresses. We use stakeholder theory to explore how CG characteristics influence CSRD (Snider et al., 2003). The contextual lens for doing so is Portugal, a small developing European Latin country that was affected strongly by the GFC. Portugal is characterized by high ownership concentration and high levels of "CEO duality" (that is, situations where the largest shareholder is also the CEO and Chair of the board).

We find that companies with large boards and CEO duality are associated with higher levels of CSRD. This can be explained by large boards (usually representing a wider range of stakeholders) operating to promote CSRD. We find that CEO duality is correlated negatively with board size, company size, and the existence of an audit committee or a CSR committee. Thus, it appears that CEO duality enhances CSRD in smaller companies with smaller boards and no audit committee or CSR committee. We find also that large companies who are close-toconsumers engage in higher levels of CSRD. These results are consistent with a view that community pressures encourage companies to focus on activities that benefit a wide range of stakeholders and the broader society. This seems particularly true in the context of a severe financial crisis.

Section 2 outlines CG rules in Portugal. Section 3 presents the theoretical framework of the study - one that focuses on the relationship between CG and CSRD from a stakeholder theory perspective. The ensuing sections develop hypotheses, describe research method, present results, offer conclusions, and suggest areas for future research. 


\section{Institutional and Regulatory Background}

Portugal has a highly concentrated universal bank system, and a very small capital market (Lopes \& Rodrigues, 2007). It has sustained severe on-going effects from the GFC (which commenced in the US in 2007). In May 2011, the International Monetary Fund, European Union, and Portuguese government, established an Economic and Financial Assistance Program to redress budget austerity and economic pessimism and to restore the confidence of international investors in Portugal. There have been continuing (but weakly effective) policy initiatives to promote competitiveness and sustainable growth in the economy (Dias et al., 2016).

The main principles and rules relating to $\mathrm{CG}$ in Portugal are contained in the Commercial Companies Code (Código das Sociedades Comerciais, CSC) and the Portuguese Securities Code (Código de Valores Mobiliários, CVM). The CSC details the composition, competence and power of company boards and management, outlines supervision models and matters relating to independence, and describes information rights and rules for shareholder participation. The CVM stipulates the legal consequences for listed companies and highlights their duty to inform shareholders (Silva et al., 2006).

Rules regulating CG by listed companies were introduced to Portuguese business practice mainly through regulations published by the Portuguese Securities Market Commission (CMVM) from 1999 onwards, inspired by the OECD (OECD, 1999; Silva et al., 2006). In 2007, CMVM recommendations were converted into the first Portuguese CG code. In 2010, the CMVM's CG Code became mandatory for listed companies. They were required to report annually on their compliance. ${ }^{4}$ In 2013, the Portuguese Institute of Corporate Governance (Instituto Português de Corporate Governance, IPCG) issued the first CG code prepared by a private entity (IPCG, 2013), as an alternative to the CMVM's CG Code. Since 2014, listed companies have been permitted to adopt whichever CG code best suits them, provided that the code is prepared by an approved institution (as is the case with the IPCG).

\section{Theoretical Framework}

In recent decades, irresponsible behavior by unscrupulous managers has increased the importance of CG, business ethics, trust, and accountability. This has led to wide acceptance that companies have formal and/or informal obligations beyond shareholders to a large set of stakeholders.

A traditional view is that CG should deal "with the ways in which suppliers of finance to corporations assure themselves of getting a return on their investment" (Shleifer \& Vishny, 1997, p. 737). From this perspective, $C G$ is the act of protecting shareholders from expropriation by managers (Mitton, 2002). The change of emphasis from a "traditional shareholder-centric approach towards a more stakeholder-oriented approach to corporate governance" (Brennan \& Solomon, 2008, p. 896) has opened CG to a broader definition. For example, the OECD (2004, p. 11) defined CG as a "set of relationships between a company's management, its board, its shareholders and other stakeholders."

\footnotetext{
${ }^{4}$ In 2013, the CMVM published an updated version: CMVM Regulation 4/2013 CG Code.
} 
Consequently, stakeholder theory is used increasingly to offer a more inclusive approach to CG (Solomon, 2007; Jamali et al., 2008). The stakeholder perspective maintains that because groups other than shareholders are affected by corporate activities, they must be considered in management decisions (Freeman, 1994). Thereby, business should be understood as a set of relationships among groups possessing a stake in the activities comprising the business (Freeman, 1994; Jones, 1995). Using the lens of stakeholder theory, CG is regarded as "the system of checks and balances, both internal and external to companies, which ensures that companies discharge their accountability to all their stakeholders and act in a socially responsible way in all areas of their business activity" (Solomon, 2007, p.14).

CG has developed to involve some aspects regarded traditionally as part of CSR (Kolk \& Pinkse, 2010). In recent decades, there has been greater acknowledgement of the links between CG and CSR (Gray et al., 1995; Jamali et al., 2008) and stronger examination of a broader range of accountability and transparency mechanisms (Brennan \& Solomon, 2008). To show a company's social performance, the board of directors assumes a greater responsibility for defining CSR goals and CSRD practices (Roberts, 1992). Gray et al. (1995, p.53) were unambiguous in asserting that "we can understand CSR reporting as a part of the dialogue between the company and its stakeholders." By providing CSRD, a company can legitimize its behavior and influence perceptions and expectations of stakeholders (Haniffa \& Hudaib, 2006; Jamali et al., 2008; Michelon \& Parbonetti, 2012).

CG drives executives to set goals and objectives relating to CSR (Jamali et al., 2008). In determining and promoting CSR targets, board structure and composition are key factors (Rao \& Tilt, 2015). There is widespread acceptance that CSRD is part of the dialogue between a company and its stakeholders, and a major way to raise public awareness of CSR activities (Said et al., 2009).

Stakeholder theory links CG and CSRD by suggesting that both should aim to enhance stakeholder engagement and organizational legitimacy (Michelon \& Parbonetti, 2012). CSRD represents a strategic response to the expectations of society (Gray et al., 1995). Developing a corporate reputation through performance and disclosure is part of a strategic approach to managing stakeholder relationships.

\section{Hypotheses}

Board Size (H1)The size of a board of directors is often used to explain matters of CG and CSRD (Zahra et al., 2000; Akhtaruddin et al., 2009). Consistent with stakeholder theory, a board's decisions relating to disclosure practices should balance the interests of all stakeholders (Kakabadse \& Kakabadse, 2007). Representation on a board can provide stakeholders with beneficial input to board-level decisions (Owen et al., 2001) and help the board "respond better to the resource dependencies the company faces" (Ayuso \& Argandoña, 2007, p.11). Thus, a larger board is likely to represent a wider range of stakeholders and promote the needs of additional groups of stakeholders. Because stakeholders usually request greater transparency, their wider representation is likely to have a positive effect on company disclosure policies. 
Previous empirical studies of the relationship between board size and levels of CSRD have yielded contradictory results. ${ }^{5}$ These results could be attributed to the existence of a non-linear quadratic relationship between board size and CSRD, as suggested by Cormier et al. (2011). In view of this, we tested the possibility of a quadratic relationship between board size and CSRD. No statistically significant relationship was found. Given the contradictory nature of prior research, we formulated the following non-directional hypothesis:

H1: Board size is related to the level of CSRD.

\section{Board Leadership (H2)}

A central CG issue is whether one person should hold the dual positions of board Chair and company CEO (Ho \&Wong 2001; Haniffa \& Hudaib, 2006; Al Mamun et al., 2013). Duality is argued to be beneficial because it provides a unified command structure and consistent leadership direction, thereby enhancing decision-making, rapid implementation of operational decisions, and company performance (Vo, 2010). A competing view is that a person who is simultaneously CEO and Chair is more likely to advance personal interests to the detriment of the company (Haniffa \& Hudaib, 2006). There is ensuing potential to decrease board independence and reduce the effectiveness and efficiency of board monitoring and controlling (Al Mamun, et al., 2013). However, Vo (2010, p. 127) cautions that "not every company that combines the CEO and Chair positions is a governance failure, and not every company that separates the CEO and Chair positions is a model of good governance."

Findings regarding the association between CEO duality and the level of disclosure are inconclusive. No association was reported by Ho and Wong (2001), Cheng and Courtenay (2006), Li et al. (2008), Said et al. (2009), Michelon and Parbonetti (2012) and Khan et al. (2013). Nonetheless, Chau and Gray (2002), Eng and Mak (2003), Gul and Leung (2004), Webb (2004), Huafang and Jianguo (2007), De Villiers et al. (2011), and Allegrini and Greco (2013) have reported a negative association between CEO duality and levels of disclosure. Al-Janadi et al. (2013) reported that companies with CEO duality provided more information than those without. As a consequence of these mixed findings, we propose a non-directional hypothesis.

H2: CEO duality is related to the level of CSRD.

\section{Board Independence (H3)}

The appointment of directors who are independent of the CEO is claimed to be an important internal CG mechanism for effective board monitoring and control (Haniffa \& Cooke, 2002; Michelon \& Parbonetti, 2012). Socially responsible companies tend to have boards with more outsider directors (Webb, 2004). This is thought to help ensure they pursue the broad interests of

\footnotetext{
${ }^{5}$ For example, three Malaysian studies have reported mixed results: Said et al. (2009) found no significant results; Htay et al. (2012) found a negative association; and Akhtaruddin et al. (2009) found a positive association. In other settings, Rouf and Harun (2011) found the relationship between board size and disclosure was not significant. Similar results were reported by Ho and Wong (2001). Cheng and Courtenay (2006) argued that larger boards are associated with greater levels of information disclosure. Similar conclusions were reached by Byard et al. (2006), De Villiers et al. (2011), Rouf (2011), Rao et al. (2012), and Allegrini and Greco (2013).
} 
shareholders and other stakeholders (Haniffa \& Cooke, 2005). Ideally, independent nonexecutive directors monitor the activities of executive directors. They are claimed to have a strong concern for the reputation of the company and its CSR programs (Zahra \& Stanton, 1988).

Empirical evidence of the effect of independent directors is mixed. Eng and Mak (2003) found a significant negative association between board independence and disclosure levels. Similar results were obtained by Gul and Leung (2004) and Huafang and Jianguo (2007). In contrast, Ho and Wong (2001) found no association between the number of outside non-executive directors and the level of disclosure. Given these contradictory results, we formulated the following nondirectional hypothesis:

H3: The proportion of independent non-executive directors on a board is related to the level of CSRD.

\section{Board Structure (H4 and H5)}

Companies establish board committees to deal with a range of financial and strategic matters. Such committees help the board to respond to the expectations of stakeholders regarding effective conduct of the company. They offer assurance to stakeholders on accounting functions and accountability matters.

The presence of an audit committee is reported to improve the effectiveness of monitoring and disclosure significantly (Ho \& Wong, 2001; Arcay \& Vazquez, 2005). The presence of an audit committee is reported to be correlated positively and significantly with the level of CSRD (Said et al., 2009; Al Shammari \& Al Sultan, 2010; Khan et al., 2013).

The establishment of a board CSR committee provides formal recognition that environmental and social impacts are under consideration and that there is an active strategic posture with regard to stakeholders (Ullman, 1985). A CSR committee is reported to improve the effectiveness of monitoring and the quality and quantity of CSRD (Michelon \& Parbonetti, 2012).

We propose the following two hypotheses:

H4: CSRD is related positively to the presence of an audit committee.

H5: CSRD is related positively to the presence of a CSR committee.

\section{Ownership Structure (H6)}

Ownership structure is influenced by country-specific CG characteristics, including the maturity of the stock market, and the nature of state intervention and regulation (La Porta et al., 2000). Shareholder structures differ across countries. In the United Kingdom and United States they are characterized by dispersed ownership. In Continental Europe and Japan, it is common to find concentrated ownership, featuring large shareholders such as families and banks (La Porta et al., 
2000). Different national dispositions to shareholding structures affect CG structure, CSR activities, and levels of CSRD.

Where ownership is concentrated, management is likely to be pressured to respond to the interests of large shareholders, to the detriment of other stakeholders. The information disclosed is likely to reflect the interests of large shareholders and their preference to limit disclosure (Fathi, 2013). On the contrary, information disclosure is likely to be more effective in companies with dispersed ownership, especially when investors are concerned with a company's broader social activities (Chan et al., 2014).

However, it is also likely that to maintain company reputation, dominant shareholders will make decisions that maximize their company's economic, social and environmental behavior (PradoLorenzo et al., 2009). Thus, dominant shareholders, particularly family groups, will increase communication of CSR matters to the market because of their special interest in the long-term survival of the company (Anderson \& Reeb, 2003). They know that investor confidence and market efficiency depend on the disclosure of accurate information about corporate performance (Jamali, et al., 2008).

Findings regarding the relationship between ownership concentration and corporate disclosure are mixed. Cormier and Magnan (2003), Brammer and Pavelin (2006), Fathi (2013), Khan et al. (2013), and Muttakin and Khan (2014) reported that the extent and quality of disclosure is influenced negatively by a concentrated ownership structure. However, Haniffa and Cooke (2002), Chau and Gray (2002) and Huafang and Jianguo (2007) reported a positive relationship between ownership concentration and disclosure. No relationship was found between ownership structure and disclosure by Gul and Leung (2004) and Oliveira et al. (2011). Because shareholding structures in Portugal are characterized by the existence of large shareholders and high ownership concentration, we hypothesize that:

H6: The level of ownership concentration is related to the level of CSRD.

\section{Research Method}

\section{Sample and data}

We examined factors influencing CG and CSRD in 48 of the 51 Portuguese listed companies (we excluded three companies because they did not have an annual reporting period ending on 31 December 2011). These 48 companies represented the following major industries: Industrial (31\%), Consumer Services (19\%) and Financial (17\%). Because they included the largest and the most visible companies in Portugal, high levels of disclosure were expected (Gray et al., 1995; Bansal, 2005).

We use "consumer proximity" to classify companies, in view of strong empirical evidence that industry classification based on "consumer proximity" explains differences in the quantity and quality of CSRD between listed companies in Portugal (Branco \& Rodrigues, 2005, 2008; Dias et al., 2016). Companies with high consumer proximity are those that expect their name to be known by the final consumer (Branco \& Rodrigues, 2008). We classify "high profile" companies 
in terms of consumer proximity as are those in household goods and textiles; beverages, food and drug retailing; telecommunications services; electricity, gas distribution, water; and banks. "Low profile" companies are all other companies.

CG data on board size, composition, leadership and ownership structure were collected from reports (mainly company annual reports) available in the Portuguese CMVM database. Information pertaining to financial statements and ownership structure were obtained from the Sabi - Bureau van Dijk Database (see www.bvdinfo.com). CSRD data were collected from annual reports, stand-alone reports, and company web sites.

\section{Dependent Variable}

Thematic content analysis (Krippendorf, 1980) was used to measure the dependent variable (CSRD). As with Gray et al. (1995), Haniffa and Cooke (2005), and Dias et al. (2016), we constructed an inclusive CSRD checklist (see Table 1). This comprised three CSR dimensions and 40 individual CSR indicators (5 economic, 20 social, 15 environmental) that allow a broad view of a company's CSR.

Choice of the 40 indicators was influenced by the world's most widely used standards on CSRD, the GRI Guidelines (Larrinaga et al., 2008). We focused especially on the GRI core indicators that represent well established CSR indicators (Dias et al., 2016). The selected items were adapted to avoid penalizing companies that did not use the GRI model. Each item scored 1 if disclosed, and zero if not. No penalty was imposed if an item was expressly considered irrelevant by a company.

For reliability and validity purposes, we repeated our coding procedures five months after the first coding, obtaining an 86\% reliability measure (Cronbach's alpha). The scores for each item were then added to derive a final score for each company. The approach to scoring is additive and equally weighted (Haniffa \& Cooke, 2005). The final CSRD index (ICSRD) was calculated as follows:

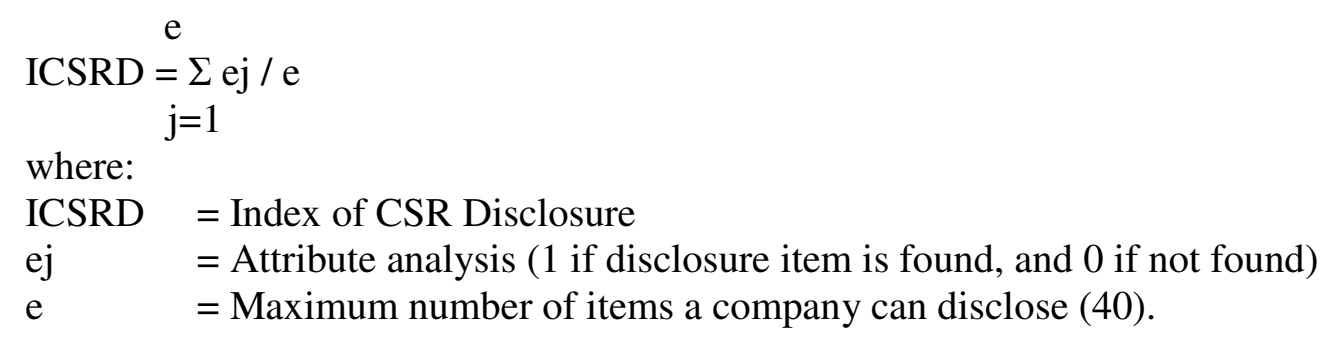

\section{Independent Variables}

The independent variables were measured as follows:

Board Size (BSIZE) = number of directors on the board.

Board Independence (BIND) = proportion of independent non-executive directors to total number of directors. 
CEO Duality (CEOD)

Audit Committee (AUDCom)

CSR Committee (CSRCom)

Ownership Structure (OWNS)
$=$ a dummy variable with the value of 1 if the CEO is also the Chair, and 0 otherwise.

= a dummy variable with a value of 1 if the company has an audit committee, and 0 otherwise.

= a dummy variable with a value of 1 if the company has a CSR committee, and 0 otherwise.

$=$ proportion of share capital held by the major shareholder.

\section{Control Variables}

The two control variables are Industry Type (INDST) (discussed earlier) and Company Size (LnSIZE). Company size is often considered to be a significant and positive variable associated with company disclosure (Hackston \& Milne, 1996; Haniffa \& Cooke 2005; Michelon \& Parbonetti, 2012; Khan et al., 2013; Muttakin \& Khan, 2014; Muttakin et al., 2015). Because larger companies are more visible and tend to be under strong stakeholder pressure, more CSRD is expected (Branco \& Rodrigues, 2008). Consistent with Michelon and Parbonetti (2012), we measure size (LnSIZE) as the logarithm of total sales.

\section{Analysis}

Using Ordinary Least Square (OLS) multiple regression, we examined the relationship between explanatory variables and disclosure. Model 1 considers only the independent variables. Model 2 introduces the two control variables.

\section{Model 1:}

$$
\begin{aligned}
& \operatorname{ICSRD~}_{i t}=\alpha_{0}+\alpha_{1} \text { BSIZE }_{i t}+\alpha_{2} \text { CEOD }_{i t}+\alpha_{3} \text { BIND }_{i t}+\alpha_{4} \text { AUDCom }_{i t}+\alpha_{5} \text { CSRCom }+ \\
& \alpha_{6} O W N S+\varepsilon_{i t}
\end{aligned}
$$

\section{Model 2:}

$$
\begin{aligned}
& I C S R D_{i t}=\alpha_{0}+\alpha_{1} \text { BSIZE }_{i t}+\alpha_{2} \text { CEOD }_{i t}+\alpha_{3} \text { BIND }_{i t}+\alpha_{4} \text { AUDCom }_{t}+\alpha_{5} \text { CSRCom }+ \\
& +\alpha_{6} O W N S+\alpha_{7} L n S I Z E+\alpha_{8} I N D S T+\varepsilon_{i t}
\end{aligned}
$$

\section{Results}

\subsection{Descriptive Statistics}

Table 1 reports the frequency of disclosure for each of the 40 indicators comprising the CSRD index, disaggregated by CSR dimension (economic, environmental, and social). The economic dimension of CSR is the most reported (0.55), followed by the environmental dimension $(0.51)$, and the social dimension (0.45). Sixteen companies had no CSRD. The total CSR index is only 0.49 . 
Table 1: Frequency of CSR items / CSRD Index

\begin{tabular}{|c|c|c|c|}
\hline Dimension / Category & Indicators & $\mathbf{n}$ & $\%$ \\
\hline Economic & & & 0.55 \\
\hline \multirow[t]{2}{*}{ Economic Performance } & $\begin{array}{l}\text { Direct economic value generated, revenues, operating costs, employee } \\
\text { compensation, retained earnings, payments to capital providers, donations, taxes }\end{array}$ & 32 & 0.67 \\
\hline & Governmental financial assistance received & 28 & 0.58 \\
\hline \multirow[t]{2}{*}{ Market Presence } & Policy \& practices of spending on locally-based suppliers & 26 & 0.54 \\
\hline & Procedures for local hiring & 25 & 0.52 \\
\hline Indirect Impacts & Infrastructure investments \& services provided for public benefit & 22 & 0.46 \\
\hline Environmental & & & 0.51 \\
\hline \multirow[t]{2}{*}{ Materials } & Materials used & 32 & 0.67 \\
\hline & Recycled materials used & 28 & 0.58 \\
\hline \multirow[t]{2}{*}{ Energy } & Direct energy consumption & 30 & 0.63 \\
\hline & Indirect energy consumption & 27 & 0.56 \\
\hline Water & Total water withdrawal & 32 & 0.67 \\
\hline \multirow[t]{2}{*}{ Biodiversity } & Location size of land in protected biodiversity value areas & 17 & 0.35 \\
\hline & Description of significant impacts of activities on biodiversity & 14 & 0.29 \\
\hline \multirow[t]{5}{*}{ Emissions, Effluents, Waste } & Total direct \& indirect GHG emissions & 29 & 0.60 \\
\hline & Other relevant indirect GHG emissions & 27 & 0.56 \\
\hline & Total water discharge & 30 & 0.63 \\
\hline & Total weight of waste & 25 & 0.52 \\
\hline & Total number of significant spills & 11 & 0.23 \\
\hline \multirow[t]{2}{*}{ Products \& Services } & Initiatives to mitigate environmental impacts products/services & 24 & 0.50 \\
\hline & Products sold \& packaging materials reclaimed & 28 & 0.58 \\
\hline Compliance & Significant sanctions for noncompliance with environmental laws & 14 & 0.29 \\
\hline Social & & & 0.45 \\
\hline \multicolumn{4}{|l|}{ Labor Practices } \\
\hline \multirow[t]{2}{*}{ Employment } & Total workforce by employment type or contract & 32 & 0.67 \\
\hline & Information related to new employee hires and turnover & 26 & 0.54 \\
\hline Labor Relations & Employees covered by collective bargaining agreements & 23 & 0.48 \\
\hline Occupational Health/Safety & Compliance with health \& safety standards & 27 & 0.56 \\
\hline \multirow{2}{*}{$\begin{array}{l}\text { Training \& Education } \\
\text { Diversity/Equal Opportunity }\end{array}$} & Employee training & 31 & 0.65 \\
\hline & Composition of governance bodies \& breakdown of employees & 23 & 0.48 \\
\hline \multirow{4}{*}{$\begin{array}{l}\text { Human Rights } \\
\text { Investment, Procurement } \\
\text { Practices }\end{array}$} & & & \\
\hline & $\begin{array}{l}\text { Significant investment agreements \& contracts that include clauses incorporating } \\
\text { human rights concerns }\end{array}$ & 29 & 0.60 \\
\hline & $\begin{array}{l}\text { Information on significant business partners that have had human rights } \\
\text { screening }\end{array}$ & 22 & 0.46 \\
\hline & Information on education of employees on human rights & 19 & 0.40 \\
\hline \multirow{3}{*}{$\begin{array}{l}\text { Non-Discrimination } \\
\text { Freedom of Association \& } \\
\text { Collective Bargaining } \\
\text { Child Labor }\end{array}$} & Incidents related to discrimination & 12 & 0.25 \\
\hline & $\begin{array}{l}\text { Procedures to identify operations in which the right to exercise freedom of } \\
\text { association \& collective bargaining may be at risk }\end{array}$ & 15 & 0.31 \\
\hline & $\begin{array}{l}\text { Procedures to identify operations with significant risk for incidence of child labor } \\
\text { Procedures to identify suppliers with significant risk for incidence of forced or }\end{array}$ & 14 & 0.29 \\
\hline Forced \& Compulsory Labor & compulsory labor & 12 & 0.25 \\
\hline
\end{tabular}


Dias, Lima Rodrigues and Craig | Corporate Governance Effects on Social Responsibility Disclosures

\begin{tabular}{|c|c|c|c|}
\hline \multicolumn{4}{|l|}{ Society } \\
\hline Local Community & Operations to implement local community engagement \& development programs & 31 & 0.65 \\
\hline Corruption & Procedures to identify risks related to corruption & 28 & 0.58 \\
\hline Public Policy & Info related to public policy positions & 21 & 0.44 \\
\hline \multicolumn{4}{|l|}{ Product Responsibility } \\
\hline Customer Health/Safety & Info on safety $\&$ health impacts of products $\&$ services & 23 & 0.48 \\
\hline Product/Service Labeling & Type of product $\&$ service info required by laws & 18 & 0.38 \\
\hline Marketing Communication & $\begin{array}{l}\text { Programs to adhere to laws, standards, \& voluntary codes related to marketing } \\
\text { communications }\end{array}$ & 12 & 0.25 \\
\hline Compliance & $\begin{array}{l}\text { Significant fines for noncompliance with laws \& regulations concerning the } \\
\text { provision \& use of products \& services }\end{array}$ & 14 & 0.29 \\
\hline
\end{tabular}

Values lower than 0.3 are presented by three environmental indicators (biodiversity, sanctions for non-compliance with environmental standards, number of spills) and five social dimension indicators (discrimination incidents, child or forced labor risk, marketing communication, fines for noncompliance with laws, regulations concerning the provision and use of products and services). The low levels of disclosure of these indicators can be justified by many companies because they do not apply to their operations.

Descriptive statistics of the variables are reported in Table 2. The mean of the disclosure index for the entire sample is low (0.38). The range is 0 to 0.98 .

Table 2: Descriptive statistics

Continuous variables

\begin{tabular}{llllll}
\hline Variable & N & Minimum & Maximum & Mean & St. Deviation \\
ICSRD & 48 & 0.00 & 0.98 & 0.38 & 0.38 \\
BSIZE & 48 & 3.00 & 25.00 & 11.42 & 6.23 \\
BIND & 48 & 0.00 & 0.63 & 0.20 & 0.18 \\
OWNS & 48 & 6.56 & 99.85 & 41.66 & 23.72 \\
LnSIZE & 48 & 8.07 & 16.65 & 13.16 & 1.96
\end{tabular}

Categorical variables

\begin{tabular}{lllll}
\hline Variable & $\mathbf{N}$ & Dummy & Frequency & Percentage \\
CEOD & 48 & 1 (Yes) & 25 & 52.08 \\
& & 0 (No) & 23 & 47.92 \\
AUDCom & 48 & 1 (Yes) & 26 & 54.17 \\
& & 0 (No) & 22 & 45.83 \\
CSRCom & 48 & 1 (Yes) & 11 & 22.92 \\
& & 0 (No) & 37 & 77.08 \\
INDST & 48 & 1 (High visibility) & 19 & 39.58 \\
& & 0 (Low visibility) & 29 & 60.42
\end{tabular}


Board Size varies between 3 and 25 persons, averaging 11.42. Although board size is not regulated in Portugal, the maximum value (25) is similar to that of many other European countries (23 in Belgium, 24 in Austria and Spain, 25 in United Kingdom, 27 in France and Russia) (Ferreira \& Kirchmaier, 2013). The mean proportion of Independent Directors (20\%) is below the CMVM recommendation (25\%).

The mean of ownership structure (41.66\%) is high, consistent with Oliveira et al. (2011). CEO duality is present in 25 companies (52\%). This can be explained, in line with the high ownership concentration, by the fact that families dominate many Portuguese listed companies (Lopes \& Rodrigues, 2007). Twenty-six companies (54\%) had an audit committee. Eleven companies (23\%) had a CSR committee. Nineteen companies (40\%) were classified as near-to-consumer (high visibility).

\subsection{Regression Analysis}

Before conducting regression analysis, we undertook bivariate analysis. The dependent variable (ICSRD) is correlated positively with Board Size (BSIZE), Board Independence (BIND), Audit Committee (AUDCom), Company Size (LnSIZE) and Industry Type (INDST) (at the 0.01 level, 2-tailed), and with CSR Committee (CSRCom) (at the 0.05 level, 2-tailed).

Pearson and Spearman correlation coefficients indicated that multi-collinearity was not evident. None of the correlation coefficients was greater than the threshold level of 0.90 (Kennedy, 1998). We used Tolerance and Variance Inflation factors (VIF) to test for multi-collinearity in the regression models (see Table 3 ).

Table 3: Regression results

\begin{tabular}{|c|c|c|c|c|c|c|}
\hline \multirow{2}{*}{\multicolumn{2}{|c|}{ Model }} & \multirow{3}{*}{ Beta } & \multirow{3}{*}{$\frac{\mathbf{t}}{-2.052}$} & \multicolumn{3}{|c|}{ Collinearity statistics } \\
\hline & & & & Sig. & Tolerance & VIF \\
\hline \multirow[t]{7}{*}{1} & (Constant) & & & 0.047 & & \\
\hline & BSIZE & 0.636 & 4.550 & $0.000 * * *$ & 0.610 & 1.640 \\
\hline & CEOD & 0.208 & 1.694 & $0.098 *$ & 0.791 & 1.264 \\
\hline & BIND & 0.133 & 0.979 & 0.334 & 0.646 & 1.548 \\
\hline & AUDCom & 0.102 & 0.713 & 0.480 & 0.583 & 1.716 \\
\hline & CSRCom & 0.077 & 0.609 & 0.546 & 0.738 & 1.356 \\
\hline & OWNS & 0.094 & 0.806 & 0.425 & 0.880 & 1.136 \\
\hline \multirow[t]{8}{*}{2} & (Constant) & & -4.135 & 0.000 & & \\
\hline & BSIZE & 0.336 & 2.455 & $0.019 * *$ & 0.450 & 2.223 \\
\hline & CEOD & 0.303 & 2.856 & $0.007 * * *$ & 0.748 & 1.338 \\
\hline & BIND & 0.156 & 1.362 & 0.181 & 0.642 & 1.558 \\
\hline & AUDCom & 0.057 & 0.465 & 0.644 & 0.565 & 1.770 \\
\hline & CSRCom & 0.014 & 0.127 & 0.900 & 0.699 & 1.431 \\
\hline & OWNS & 0.062 & 0.630 & 0.533 & 0.855 & 1.169 \\
\hline & LnSIZE & 0.437 & 3.558 & $0.001 * * *$ & 0.559 & 1.788 \\
\hline
\end{tabular}


Dias, Lima Rodrigues and Craig | Corporate Governance Effects on Social Responsibility Disclosures

\begin{tabular}{lrcrrrr}
\multicolumn{1}{c}{ INDST } & 0.205 & 1.844 & $0.073 *$ & 0.681 & 1.468 \\
\hline \multicolumn{2}{l}{ Significant at the } & $* * * 0.01$ level; $* * 0.05$ level; * 0.1 level & & & \\
& & & & & & \\
Model & RSquare & Adjusted RSquare & F Value & Sig. & Durbin-Watson \\
$\mathbf{1}$ & 0.512 & 0.440 & 7.164 & .000 & \\
$\mathbf{2}$ & 0.671 & 0.604 & 9.964 & .000 & 2.341
\end{tabular}

All tolerance values exceed 0.10 (Menard, 1995). The VIF for all independent variables are at acceptable levels (between 1.136 and 2.223), well below the threshold VIF value of 10 (Kennedy, 1998; Haniffa \& Cooke, 2005), indicating the absence of multi-collinearity.

In Model 1 (examining explanatory variables only) $R^{2}$ is 0.512 , adjusted $R^{2}$ is 0.440 , and $F$ is 7.164 (significant at 0.001 ). In Model 2 (examining explanatory variables and control variables) $R^{2}$ is 0.671 , adjusted $R^{2}$ is 0.604 , and $F$ is 9.964 (significant at 0.001 ). This suggests that a high percentage of the variation in CSRD is explained by variations in the whole set of independent variables.

In Model 1, the size of the board of directors (BSIZE) is positive and significant at the 0.01 level. With the introduction of control variables (in Model 2), BSIZE is still significant, but now at the 0.05 level. The results for Models 1 and 2 support H1. They suggest that a larger board will disclose more information than a smaller one. Similar conclusions are reported by Zahra et al. (2000), Cheng and Courtenay (2006), Byard et al. (2006), Akhtaruddin et al. (2009), De Villiers et al. (2011), Rouf (2011) and Rao et al. (2012). The result accords with suggestions implicit in stakeholder theory that a larger board will represent a broader diversity of stakeholders and will promote more assertive stakeholder management, leading to greater transparency and increased CSRD.

CEO duality is significant at the 0.1 level in Model 1 and at the 0.01 level in Model 2, supporting $\mathrm{H} 2$, and suggesting that CEO duality increases CSRD. This is an important finding because prior studies have reported conflicting results. The majority of studies report a negative or non-existent association between CEO duality and CSRD. However, the results lend support to findings reported by Al-Janadi et al. (2013) that companies with CEO duality provide more information than those without CEO duality.

The interpretation of results should take account of the high levels of ownership concentration in Portugal. The CEO is often the Chair and is frequently an important shareholder. The significant negative correlation between CEO Duality (CEOD) and Corporate Size (LnSIZE) (0.01 level) indicates that smaller companies, in which the CEO is also the board Chair, disclose more CSR information. This can be explained by argument that, in a period of financial crisis featuring strong concern by companies for stakeholder management (particularly in respect of community relations) (Dias et al., 2016), CEO duality strengthens the commitment the CEO and Chair to improve CSRD — and thereby, their company's image with stakeholders (Jamali et al., 2008). 
In line with stakeholder theory, managers will seek to gain and/or retain the support of all stakeholders, balance the competing interests of stakeholders, and maximize stakeholder interests over time. From this viewpoint, a strategic plan for managing stakeholder relationships might reasonably involve developing a company's reputation for social responsibility - through performing CSR and disclosing CSR activities (Chan et al., 2014).

If CSR activities are viewed as part of a company's strategic management plan to meet stakeholder demands, it is reasonable to expect a positive relationship between CEOD and CSRD. A CEO who is also Chair can exert greater authority in making and implementing strategic decisions (Vo, 2010) - such as engaging in, and reporting on, CSR activities. A CEO/Chair will be mindful that a company's stakeholders are likely to question the board's independence and ability to control company decisions effectively and efficiently. In such a case, CSRD provides a convenient mechanism for the CEO/Chair to show that the board works in the best interests of all stakeholders, and thereby, to avoid pressure from society in a period of financial crisis.

In Spain (like Portugal) boards are characterised by powerful executives (through CEO duality) and strong ownership concentration. In a study of the disclosure of strategic information by Spanish companies, Sanchez et al. (2011) found that disclosure was high in companies with CEO duality, and that the positive role of CEO duality "could be justified by the stakeholder model hypothesis, in which managers are not opportunistic agents but rather moral individuals and their role is seen as achieving a balance between the interests of all stakeholders" (p.492). Another possible explanation, is that CEO duality "provides the power and ability to shape the company in achieving its objectives and strategies because there is no intervention from one position holder or contradiction between the two positions" (Al-Janadi et al., 2013, p. 32).

Company size (LnSIZE) (statistically significant in Model 2) suggests that larger companies disclose more information. This is consistent with research reported by Ho and Wong (2001), Haniffa and Cooke (2005), Rouf (2011), Michelon and Parbonetti (2012), Khan et al. (2013), and Muttakin et al. (2015) and points to the likelihood that larger companies give more attention to managing their stakeholders and have strategies to increase CSRD.

Industry Type (INDST) (significant at the 0.1 level) suggests that companies closer to consumers are more visible and subject to public and media pressure. Thus, they have higher levels of CSRD (Bansal, 2005; Branco \& Rodrigues, 2008; Dias et al., 2016).

Board Independence (BIND), Ownership Structure (OWNS), Audit Committee (AUDCom), and CSR Committee (CSRCom), are not statistically significant. Thus, hypotheses H3, H4, H5 and H6 are not confirmed. In Portugal, independent board members are not very effective, consistent with Fernandes (2008). This possibly accounts for why BIND is not significant. AUDCom and CSRCom lose significance in the multivariate analysis because of the dominance of the board size variable. (BSIZE is correlated negatively with OWNS, and correlated positively with AUDCom and CSRCom). 


\section{Conclusions}

In a country characterized by high ownership concentration, CEO duality has a positive effect on CSRD - and stakeholder theory can explain this. CSRD was affected positively by two CG variables, board size and CEO duality; and by two control variables, company size and industry type. We conclude that larger companies, and companies closer to consumers, are associated with high levels of CSRD. Such companies are more visible and are subject to greater societal and media pressure. They are well-placed in terms of resources to adopt formal strategic policies and procedures with respect to CSR (Russo \& Tencati, 2009). Larger boards incorporate a wider range of experiences and knowledge. Thus, they are able to represent a large spectrum of stakeholders by providing more CSRD (Haniffa \& Hudaib, 2006; Akhtaruddin et al., 2009).

When the CEO is also the Chair of the board, there is greater concern for stakeholders (consistent with Sanchez et al., 2011, and Al-Janadi et al., 2013). Through CSRD, smaller companies with smaller boards (and no audit committee or CSR committee), can demonstrate greater accountability and transparency. The CEO/Chair is aware of stakeholders' interests and is well placed to promote the CSR information stakeholders require. In the analyzed period of deep financial crisis for Portugal, a CEO who is also Chair has incentives to make the company appear modern and "in tune" with society. By demonstrating engagement in activities that promote long-run benefits for society, and minimizing the negative effects of their actions, CSRD helps companies maintain reputation and build a good relationship with stakeholders.

Since different institutional factors or different legal requirements influence CSRD, it would seem beneficial for future research to explore other countries with different CG characteristics; examine the relationship between other CG factors (including gender) and levels of CSRD; and explore the relationships between CG and CSRD in non-listed companies. 


\section{References}

Akhtaruddin, M., Hossain, M.A., Hossain, M., and Yao, L. (2009), "Corporate governance and voluntary disclosure in corporate annual reports of Malaysian listed firms", Journal of Applied Accounting Research, Vol. 7 No. 1, pp. 1-19.

Al Mamun, A., Yasser, Q. and Rahman, M. (2013), "A discussion of the suitability of only one vs more than one theory for depicting corporate governance", Modern Economy, Vol. 4 No. 1, pp. 37-48. https://doi.org/10.4236/me.2013.41005

Al Shammari, B. and Al Sultan, W. (2010), "Corporate governance and voluntary disclosure in Kuwait", International Journal of Disclosure and Governance, Vol. 7, pp. 262-280. https://doi.org/10.1057/jdg.2010.3

Al-Janadi, Y., Rahman, R. and Omar, N. (2013), "Corporate governance mechanisms and voluntary disclosure in Saudi Arabia", Research Journal of Finance and Accounting, Vol. 4 No. 4, pp. 25-35.

Allegrini, M. and Greco, G. (2013), "Corporate boards, audit committees and voluntary disclosure: Evidence from Italian listed companies", Journal of Management and Governance, Vol. 17 No. 1, pp. 187-216. https://doi.org/10.1007/s10997-011-9168-3

Anderson, R. and Reeb, D. (2003), "Founding-family ownership and firm performance: Evidence from the S\&P 500", The Journal of Finance, Vol. LVII No. 3, pp. 1301-1328. https://doi.org/10.1111/1540-6261.00567

Arcay, M. and Vazquez, M. (2005), "Corporate characteristics, governance rules and the extent of voluntary disclosure in Spain", Advances in Accounting, Vol. 21, pp. 299-331. https://doi.org/10.1016/S0882-6110(05)21013-1

Archel, P. (2003), "La divulgación de la información social y medioambiental de la gran empresa española en el período 1994-1998: situación actual y perspectivas", Revista Española de Financiación y Contabilidad, Vol. 117, pp. 571-601.

Ayuso, S. and Argandoña, A. (2007), "Responsible corporate governance: towards a stakeholder board of directors?" Working paper No. 701, IESE Business School, University of Navarra Barcelona, July.

Bansal, P. (2005), "Evolving sustainably: a longitudinal study of corporate sustainable development", Strategic Management Journal, Vol. 26 No. 3, pp. 197-218. https://doi.org/10.1002/smj.441

Brammer, S. and Pavelin, S. (2006), "Voluntary environmental disclosures by large UK companies", Journal of Business Finance \& Accounting, Vol. 33 No. (7-8), pp. 1168-1188. https://doi.org/10.1111/i.1468-5957.2006.00598.x

Branco, M. and Rodrigues, L.L. (2005), "An exploratory study of social responsibility disclosure on the internet by Portuguese listed companies", Social Responsibility Journal, Vol. 1 No. 2 , pp. 81-90. https://doi.org/10.1108/eb045798

Branco, M. and Rodrigues, L.L. (2007), "Positioning stakeholder theory within the debate on corporate social responsibility", Electronic Journal of Business Ethics and Organization Studies, Vol. 12 No. 1, pp. 5-15.

Branco, M. and Rodrigues, L.L. (2008), "Factors influencing social responsibility disclosure by Portuguese companies", Journal of Business Ethics, Vol. 8, pp. 685-701. https://doi.org/10.1007/s10551-007-9658-z 
Brennan, N., and Solomon, J. (2008), "Corporate governance, accountability and mechanisms of accountability: an overview", Accounting, Auditing \& Accountability Journal, Vol. 21 No. 7, pp. 885-906. https://doi.org/10.1108/09513570810907401

Byard, D., Li, Y. and Weintrop, J. (2006), "Corporate governance and the quality of financial analysts' information", Journal of Accounting and Public Policy, Vol. 25 No. 5, pp. 609625. https://doi.org/10.1016/j.jaccpubpol.2006.07.003

Chan, M., Watson, J. and Woodliff, D. (2014), "Corporate governance quality and CSR disclosures", Journal of Business Ethics, Vol. 125 No. 1, pp. 59-73. https://doi.org/10.1007/s10551-013-1887-8

Chau, G. and Gray, S. (2002), "Ownership structure and corporate voluntary disclosure in Hong Kong and Singapore”, International Journal of Accounting, Vol. 37 No. 2, pp. 247-265. https://doi.org/10.1016/S0020-7063(02)00153-X

Cheng, C. and Courtenay S. (2006), "Board composition, regulatory regime and voluntary disclosure", International Journal of Accounting, Vol. 41, pp. 262-289. https://doi.org/10.1016/j.intacc.2006.07.001

Comissão do Mercado de Valores Mobiliários (1999), "Recomendações da CMVM sobre o governo das sociedades cotadas", CMVM, Lisboa.

Cormier, D. and Magnan, M. (2003), "Environmental reporting management: a continental European perspective", Journal of Accounting and Public Policy, Vol. 22 No. 1, pp. 43-62. https://doi.org/10.1016/S0278-4254(02)00085-6

Cormier, D., Ledoux, M. and Magnan, M. (2011), "The informational contribution of social and environmental disclosures for investors", Management Decision, Vol. 49 No. 8, pp. 12761304. https://doi.org/10.1108/00251741111163124

De Villiers, C., Naiker, V., and van Staden, C. (2011), "The effect of board characteristics on firm environmental performance", Journal of Management, Vol. 37, pp. 1636-1663. https://doi.org/10.1177/0149206311411506

Dias, A., Rodrigues, L.L. and Craig, R. (2016), "Global financial crisis and corporate social responsibility disclosure", Social Responsibility Journal, Vol. 12 No. 4, pp. 654 - 671. https://doi.org/10.1108/SRJ-01-2016-0004

Eng, L. and Mak, Y. (2003), "Corporate governance and voluntary disclosure", Journal of Accounting and Public Policy, Vol. 22 No. 4, pp. 325-345. https://doi.org/10.1016/S0278-4254(03)00037-1

Fathi, J. (2013), "Corporate governance and the level of financial disclosure by Tunisian firm", Journal of Business Studies Quarterly, Vol. 4 No. 3, pp. 95-111.

Fernandes, N. (2008), "Board compensation and firm performance: The role of "independent" board members", Journal of Multinational Financial Management, Vol. 18, pp. 30-44. https://doi.org/10.1016/..mulfin.2007.02.003

Ferreira, D. and Kirchmaier, T. (2013), "Corporate boards in Europe: size, independence and gender diversity", in Belcredi, M. and Ferrarini, G. (Eds.), Boards and shareholders in European listed companies, international corporate law and financial market regulation, Cambridge University Press, Cambridge, pp. 191-224. https://doi.org/10.1017/cbo9781139629126.004

Freeman, R. (1994), "The politics of stakeholder theory: Some future directions", Business Ethics Quarterly, Vol. 4 No. 4, pp. 409-421. https://doi.org/10.2307/3857340

Gray, R., Kouhy, R., and Lavers, S. (1995), "Corporate social and environmental reporting: a review of the literature and a longitudinal study of UK disclosure", Accounting, Auditing \& Accountability Journal, Vol. 8 No. 2, pp. 47-77. https://doi.org/10.1108/09513579510146996 
Gul, F. and Leung, S. (2004), "Board leadership, outside directors expertise and voluntary corporate disclosures", Journal of Accounting and Public Policy, Vol. 23, pp. 351-379. https://doi.org/10.1016/j.jaccpubpol.2004.07.001

Hackston, D. and Milne, M. (1996), "Some determinants of social and environmental disclosures in New Zealand companies", Accounting, Auditing \& Accountability Journal, Vol. 9 No. 1, pp. 77-108. https://doi.org/10.1108/09513579610109987

Haniffa, R. and Cooke, T. (2002), "Culture, corporate governance and disclosure in Malaysian corporations", Abacus, Vol. 38 No. 3, pp. 317-349. https://doi.org/10.1111/1467-6281.00112

Haniffa, R. and Cooke, T. (2005), "The impact of culture and governance on Corporate Social Reporting", Journal of Accounting and Public Policy, Vol. 24 No. 5, pp. 391-430. https://doi.org/10.1016/j.jaccpubpol.2005.06.001

Haniffa, R. and Hudaib, M. (2006), "Corporate governance structure and performance of Malaysian listed companies", Journal of Business Finance \& Accounting, Vol. 33 No. 7-8, pp. 1034-1062. https://doi.org/10.1111/j.1468-5957.2006.00594.x

Ho, S. and Wong, K. (2001), "A study of the relationship between corporate governance structure and the extent of voluntary disclosure", Journal of International Accounting Auditing and Taxation, Vol. 10 No. 2, pp. 139-156. https://doi.org/10.1016/S1061-9518(01)00041-6

Htay, S., Rashid, H., Adnan, M. and Meera, A. (2012), "Impact of corporate governance on Social and environmental information disclosure of Malaysian listed banks: Panel data analysis", Asian Journal of Finance and Accounting, Vol. 4 No. 1, pp. 1-24. https://doi.org/10.5296/ajfa.v4i1.810

Huafang, X. and Jianguo, Y. (2007), "Ownership structure, board composition and corporate voluntary disclosure: Evidence from listed companies in China", Managerial Auditing Journal, Vol. 22 No. 6, pp. 604-619. https://doi.org/10.1108/02686900710759406

Instituto Português de Corporate Governance (2013), Código de Governo das Sociedades, IPCG, Lisboa.

Jamali, D., Safieddine, A., and Rabbath, M. (2008), "Corporate governance and corporate social responsibility synergies and interrelationships", Corporate Governance: An International Review, Vol. 16 No. 5, pp. 443-459. https://doi.org/10.1111/j.1467-8683.2008.00702.x

Jones, T. (1995), "Instrumental stakeholder theory: A synthesis of ethics and economics", Academy of Management Review, 20, pp. 404-437. https://doi.org/10.5465/AMR.1995.9507312924

Kakabadse, N. and Kakabadse, A. (2007), "CSR in the boardroom: Myth or mindfulness", in Corporate social responsibility in practice: Delving deep, Palgrave Macmillan, London, pp. 180-205.

Kennedy, P. (1998), A guide to econometrics, MIT Press, Cambridge, MA.

Khan, A., Muttakin, M. and Siddiqui, J. (2013), "Corporate governance and corporate social responsibility disclosures: Evidence from an emerging economy", Journal of Business Ethics, Vol. 114 No. 2, pp. 207-223. https://doi.org/10.1007/s10551-012-1336-0

Kolk, A., and Pinkse, J. (2010), "The integration of corporate governance in corporate social responsibility disclosures", Corporate Social Responsibility and Environmental Management, Vol. 17 No. 1, pp. 15-26.

Krippendorf, K. (1980), Content analysis: An introduction to its methodology, Sage, New York, NY.

La Porta, R., Lopez-de-Silane, F., Shleifer, A. and Vishny, R. (2000), "Agency problems and dividend policies around the world”, Journal of Finance, Vol. 55 No. 1, pp. 1-33. 
https://doi.org/10.1111/0022-1082.00199

Larrinaga, C., Archel, P. and Fernández, M. (2008), "The organizational and operational boundaries of triple bottom line reporting: a survey", Environmental Management, Vol. 41 No. 1, pp. 106-117. https://doi.org/10.1007/s00267-007-9029-7

Li J., Pike R. and Haniffa, R. (2008), "Intellectual capital disclosure and corporate governance structure in UK firms", Accounting and Business Research, Vol. 38 No. 2, pp. 137-159. https://doi.org/10.1080/00014788.2008.9663326

Lopes, P.T., and Rodrigues, L.L. (2007), "Accounting for financial instruments: An analysis of the determinants of disclosure in the Portuguese stock exchange", The International Journal of Accounting, Vol. 42 No. 1, pp. 25-56. https://doi.org/10.1016/j.intacc.2006.12.002

Menard, S. (2002), Applied logistic regression analysis. Sage, Thousand Oaks, California, CA. https://doi.org/10.4135/9781412983433

Michelon, G., and Parbonetti, A. (2012), "The effect of corporate governance on sustainability disclosure", Journal of Management and Governance, Vol. 16 No. 3, pp. 477-509. https://doi.org/10.1007/s10997-010-9160-3

Mitton, T. (2002), "A cross-firm analysis of the impact of corporate governance on the East Asian financial crisis", Journal of Financial Economics, 64 No. 2, pp. 215-241. https://doi.org/10.1016/S0304-405X(02)00076-4

Muttakin, M., Khan, A. and Subramaniam, N. (2015), "Firm characteristics, board diversity and corporate social responsibility: Evidence from Bangladesh", Pacific Accounting Review, Vol. 27 No. 3, pp. 353 - 372. https://doi.org/10.1108/PAR-01-2013-0007

OECD (1999), Principles of corporate governance, OECD, Paris.

OECD (2004), Principles of corporate governance, OECD, Paris.

Oliveira, J., Rodrigues, L.L., and Craig, R. (2011), "Risk-related disclosures by non-finance companies: Portuguese practices and disclosure characteristics", Managerial Auditing Journal, Vol. 26 No. 9, pp. 817-839. https://doi.org/10.1108/02686901111171466

Owen, D., Swift, T. and Hunt, K. (2001), "Questioning the role of stakeholder engagement in social and ethical accounting, auditing and reporting", Accounting Forum, Vol. 25 No. 3, pp. 264-282. https://doi.org/10.1111/1467-6303.00066

Prado-Lorenzo, J., Gallego-Alvarez, I. and Garcia-Sanchez, I. (2009), "Stakeholder engagement and corporate social responsibility reporting: the ownership structure effect", Corporate Social Responsibility and Environmental Management, Vol. 16 No. 2, pp. 94-107. https://doi.org/10.1002/csr.189

Rao, K. and Tilt, C. (2015), "Board composition and corporate social responsibility: the role of diversity, gender, strategy and decision making", Journal of Business Ethics, pp. 1-21.

Rao, K., Tilt, C. and Lester, L. (2012), "Corporate governance and environmental reporting: an Australian study", Corporate Governance: The International Journal of Business in Society, Vol. 12 No. 2, pp. 143-163. https://doi.org/10.1108/14720701211214052

Roberts, R. (1992), "Determinants of corporate social responsibility disclosure: an application of stakeholder theory", Accounting Organizations and Society, Vol. 17 No. 6, pp. 595-612. https://doi.org/10.1016/0361-3682(92)90015-K

Rouf, M. (2011), "The relationship between corporate governance and value of the firm in developing countries: Evidence from Bangladesh", International Journal of Applied Economics and Finance, Vol. 5, pp. 237-244. https://doi.org/10.3923/ijaef.2011.237.244

Russo, A., and Tencati, A. (2009), "Formal vs. informal CSR strategies: Evidence from Italian micro, small, medium-sized, and large firms", Journal of Business Ethics, Vol. 85 No. 2, pp. 339-353. https://doi.org/10.1007/s10551-008-9736-x 
Said, R., Zainuddin, Y., and Haron, H. (2009), "The relationship between corporate social responsibility disclosure and corporate governance characteristics in Malaysian public listed companies”, Social Responsibility Journal, Vol. 5 No. 2, pp. 212-226. https://doi.org/10.1108/17471110910964496

Shleifer, A. and Vishny, R. (1997), "A survey of corporate governance", Journal of Finance, Vol. 52 No. 2, pp. 737-783. https://doi.org/10.1111/j.1540-6261.1997.tb04820.x

Silva, A., Vitorino, A., Alves, C., Cunha, J. e Monteiro, M. (2006), "Livro Branco sobre corporate governance em Portugal", Instituto Português de Corporate Governance, IPCG, Lisbon.

Snider, J., Hill, R. and Martin, D. (2003), "Corporate social responsibility in the 21st century: A view from the world's most successful firms", Journal of Business Ethics, Vol. 48 No. 2, pp. 175-187. https://doi.org/10.1023/B:BUSI.0000004606.29523.db

Solomon, J. (2007), Corporate Governance and Accountability, Wiley, Chichester, UK.

Vo, T. (2010), "To be or not to be both CEO and Board Chair", Brooklyn Law Review, Vol. 76, pp. 65-129.

Webb, E. (2004), “An examination of socially responsible firms' board structure”, Journal of Management and Governance, Vol. 8, pp. 255-277. https://doi.org/10.1007/s10997-004-1107-0

Zahra, S. and Stanton, W. (1988), "The implications of board of directors composition for corporate strategy and performance", International Journal of Management, Vol. 5 No. 2, pp. 229-236.

Zahra, S., Neubaum, D. and Huse, M. (2000), "Entrepreneurship in medium-size companies: Exploring the effects of ownership and governance systems", Journal of Management, Vol. 26 No. 5, pp. 947-976. https://doi.org/10.1177/014920630002600509 